\title{
WSPÓŁCZESNY PRZEDSIĘBIORCA JAK DOBRY SAMARYTANIN
}

Współczesnego przedsiębiorcę kierującego się w biznesie etyką chrześcijańską możemy przyrównać do podróżnego z ewangelicznej przypowieści o miłosiernym Samarytaninie. Podróżny udający się z Jerozolimy do Jerycha napotkał człowieka napadniętego i okaleczonego przez zbójców. Postanowił się nim zaopiekować. Opatrzył mu rany, wsadził na swoje bydlę i zawiózł do gospody, prosząc gospodarza o dalszą opiekę. Ale istotne jest, że za opiekę nad poszkodowanym gospodarzowi zapłacił (por. Łk, 10, 30-37). Kim był miłosierny Samarytanin z ewangelicznej przypowieści, bliżej nie wiemy. Możemy go sobie wyobrazić jako ówczesnego przedsiębiorcę. Z całą pewnością nie był bowiem człowiekiem ubogim, skoro stać go było na pobyt w gospodzie i na wydanie 2 denarów za opiekę nad nieznajomym. Możemy też sobie wyobrazić go jako kupca, który podróżował w celach handlowych.

Nie każdy człowiek zdolny do pracy ma dar przedsiębiorczości. Pomyślność w prywatnych przedsięwzięciach gospodarczych uwarunkowana jest takimi cechami, jak kreatywność, umiejętność myślenia strategicznego, cierpliwość i wiara w końcowy sukces. Te niezbędne cechy posiada niewielu z nas. Aktywność zawodowa ludzi powinna być dostosowana do ich zdolności. Przypomina nam o tym ewangeliczna przypowieść o talentach. Pewien bogaty człowiek, według tej przypowieści, postanowił podzielić nagromadzony majątek pomiędzy swoje sługi, aby go pomnożyli. Majątku nie przydzielił jednak każdemu słudze po równo, lecz według ich zdolności. Jednemu dał pięć talentów, drugiemu dwa talenty a trzeciemu tylko jeden (por. Mt, 25, 14-31). Świadom był zapewne różnej zdolności obdarowanych do pomnażania kapitału. Miał zresztą rację, bo tylko dwaj pierwsi słudzy, którzy dostali najwięcej, zdołali podwoić otrzymany darmo kapitał. Zresztą i oni uzyskali odmienne rezultaty. Pierwszy zdołał zarobić dodatkowo pięć talentów, a drugi sługa tylko dwa talenty. Trzeci sługa okazał się nieudolny, gdyż nie potrafił uzyskać nic więcej ponad to, co otrzymał. Nie nadawał się więc na przedsiębiorcę, co oczywiście nie znaczy, że nie mógł być dobrym pracownikiem i szlachetnym człowiekiem. Jednak nie był kreatywny. Zakopał kapitał, 
który otrzymał, naiwnie wierząc, że postępuje właściwie. Był uczciwy, bo w ostateczności otrzymanego kapitału nie roztrwonił. Nie osiągnął też wszakże celu, który wskazał mu właściciel majątku. Dar przedsiębiorczości, czyli dar pomnażania zasobów materialnych należy bowiem uznać za dar szczególny, cechę pozytywną. Istota pomnażania kapitału wiąże się jednak zawsze z motywacją temu towarzyszącą. I od charakteru tej motywacji zależy akceptacja społecznej nauki Kościoła dla sensu materialnej aktywności człowieka. Jak w przypowieści o talentach, pomnożony kapitał powinien prowadzić człowieka do umocnienia wiary i pomnażania owoców Dobrej Nowiny.

Nierzadko nasze potencjalne talenty są marnowane z powodu braku środków materialnych potrzebnych do ich rozwoju. Niezbędnym warunkiem osiągnięcia sukcesu w życiu zawodowym jest bowiem wykształcenie, które przecież kosztuje. Iluż to współczesnych Janków muzykantów marnuje swoje zdolności $\mathrm{z}$ braku niezbędnych środków materialnych potrzebnych do ich doskonalenia. Możemy nawet powiedzieć, że tak się dzieje z większością młodych ludzi żyjących w niedostatku. Dotyczy to między innymi młodych, kreatywnych ludzi, mających szansę odnosić sukcesy w biznesie. Szlifowanie takich talentów warto jest wspierać poprzez ułatwienie im dostępu do wykształcenia. Jakże wielkim darem jest materialne wsparcie nauczania młodzieży z rodzin ubogich w ramach fundacji Dzieło Nowego Tysiąclecia, którą zainicjował papież Jan Paweł II. Z pewnością znajdują się wśród nich przyszli szlachetni przedsiębiorcy, współcześni miłosierni samarytanie, którzy będą kierować się w życiu zawodowym etyką chrześcijańską.

Zysk nigdy nie może być ostatecznym celem aktywności życiowej chrześcijanina. Powinien pełnić rolę służebną, czyli umożliwiać czynienie dobra, tak jak to miało miejsce w przypowieści o miłosiernym Samarytaninie. Zysk zatem powinien być przeznaczony na cele godziwe, społecznie użyteczne, uwiarygodniające postępowanie prawdziwie chrześcijańskie. Ma też służyć doskonaleniu chrześcijańskich stosunków międzyludzkich W pierwszej kolejności odnosi się to do relacji pracodawca - pracownik. Przedsiębiorca ma obowiązek dbać o swych pracowników, gdyż to oni tworzą nową wartość w przedsiębiorstwie. Sam kapitał rzeczowy i finansowy niewiele jest wart, jeżeli nie zostanie aktywnie przekształcony przez pracownika w procesie produkcji. Sukces ekonomiczny przedsiębiorcy zależy od trudu zatrudnionych. Dlatego powinien on godziwie ich wynagradzać. Święty Jan Paweł II w encyklice Laborem exercens nauczał, że płaca sprawiedliwa powinna wystarczyć na realizację potrzeb duchowo-materialnych pracownika i jego rodziny. Powinna też być na takim poziomie, aby było możliwe odłożenie jej części na potrzeby materialne w wieku poprodukcyjnym. Nie da się realizować koncepcji płacy godziwej bez ograniczenia niepohamowanego pędu biznesu do maksymalizacji zysku. Zwłaszcza w okresach kryzysów przedsię- 
biorcy powinni zmniejszyć margines swoich zysków, tak aby pracownicy nie byli zwalniani z powodu zastoju w gospodarce.

Trudno byłoby stwierdzić, że w Polsce jest realizowana taka koncepcja pracy sprawiedliwej, jaką zaproponował święty Jan Paweł II. W naszym kraju nie jest nawet przestrzegana przez prywatnych pracodawców wypłata ustawowej płacy minimalnej. Płaca minimalna umożliwia zaledwie biologiczne przetrwanie, regenerację sił fizycznych pracownika do dalszego funkcjonowania. Tymczasem aż 20 proc. zatrudnionych w Polsce zarabia poniżej ustawowego minimalnego wynagrodzenia, gwarantującego regenerację sił do dalszej pracy. Płace w Polsce są jednymi z najniższych w Europie. Rzeczą moralnie naganną, ale niestety częstą, jest zjawisko wypłaty wynagrodzeń z opóźnieniem. Tworzy to upokarzającą sytuację, kiedy brakuje środków do życia dla całej rodziny pracownika. Powoduje konieczność zadłużania się celem przetrwania do następnej wypłaty. Innym negatywnym zjawiskiem jest zaniżanie wynagrodzeń wbrew uzgodnionej umowie o pracę. Za godne potępienia należy uznać zatrudnianie pracowników na czarno, bez zagwarantowania jakichkolwiek praw do urlopów, ubezpieczenia zdrowotnego i wysługi emerytalnej. Taki sposób zatrudniania pracowników równoznaczny jest $\mathrm{z}$ niewolnictwem rynkowym. Tymczasem jest on w Polsce rozpowszechniony. Jak wynika z badania Głównego Urzędu Statystycznego, w 2014 roku na czarno pracowało w Polsce 711 tysięcy osób. Dziesięć lat wcześniej tak zatrudnionych było aż 1,3 mln osób. Liczba osób nierejestrowanych w pracy wprawdzie maleje, ale i tak aktualny stan tego zjawiska jest zatrważający. Pracownicy zatrudnieni na czarno zarabiają bowiem mniej, aniżeli wynosi ustawowa płaca minimalna. Dane GUS wskazują, że praca na czarno ma zazwyczaj charakter doraźny, krótkotrwały. Prawie 90 proc. pracujących w szarej strefie w 2014 roku miało zatrudnienie tylko 1 raz w miesiącu. W szarej strefie pracują wszystkie generacje Polaków, od młodzieży po osoby w wieku emerytalnym. Niewiele lepsza jest sytuacja pracowników zatrudnionych $\mathrm{w}$ ramach śmieciowych umów zleceń. Im też nie przysługują żadne prawa pracownicze poza prawną gwarancją wypłaty uzgodnionego wynagrodzenia. Tymczasem w Polsce aż 2,5 mln ludzi zatrudnionych jest właśnie w formie umów śmieciowych.

Niskie płace ograniczają popyt i konsumpcję. Pracownicy są przecież także odbiorcami dóbr i usług. To właśnie niskie płace, ograniczając konsumpcję, prowadzą do kryzysów. Papież Franciszek mówił, iż „sprawiedliwy podział owoców ziemi i pracy ludzkiej to nie filantropia, lecz moralny obowiązek"1.

Rzeczywistość polskiej gospodarki niestety przeczy postulatom społecznego nauczania Kościoła. Obciążenie produktu krajowego brutto w Polsce koszta-

1 http://ekai.pl/wydarzenia/ostatnia_chwila/x84154/mysl-spoleczna-papiezafranciszka (2.10.2016). 
mi związanymi z zatrudnieniem spadło w Polsce w latach 2000-2011 z 40 proc. do 36 proc. PKB. Jednostkowe koszty pracy obniżyły się. Stało się tak, ponieważ w tym okresie szybciej rosła wydajność pracy. Owoce wzrostu produktywności pracowników przechwycili więc pracodawcy. Nic dziwnego, że zyski przedsiębiorstw rosły znacznie szybciej niż fundusz wynagrodzeń pracowników. Niskie płace były źródłem wysokiego bezrobocia w Polsce. Sektor wytwórczy nie miał bowiem dla kogo produkować z powodu niskich dochodów obywateli. Były też powodem ogromnego exodusu rodaków za granicę za chlebem. Według danych Głównego Urzędu Statystycznego w 2014 roku ok. 2,8 mln ludzi w Polsce żyło w skrajnym ubóstwie. Z tej liczby aż jedną trzecią stanowili ludzie poniżej 18 . roku życia. GUS zwraca też uwagę, że sytuacja bezrobocia, niskiego wykształcenia, zamieszkanie na wsi i obecność w gospodarstwie domowym osoby niepełnosprawnej zwiększały stan zagrożenia ubóstwem.

Za etycznie naganną z chrześcijańskiego punktu widzenia należy uznać nierzadką praktykę wymuszania pracy ponad wymagane normy dla osiągnięcia dodatkowego zysku. Wydłużanie czasu pracy bez dodatkowego wynagrodzenia i oszczędzanie na właściwym technicznym wyposażeniu stanowisk pracy prowadzą do dużej wypadkowości zatrudnionych. Brak właściwych warunków w miejscu pracy jest plagą w polskim sektorze prywatnym. Przedsiębiorcy często oszczędzają na wydatkach wiążących się z ochroną stanowisk pracy. Sprawia to, że wskaźnik wypadkowości, a nawet śmiertelności w miejscu pracy jest w Polsce na tle innych krajów europejskich wysoki. Szczególnie jaskrawym przykładem tej sytuacji są warunki zatrudnienia w sektorze budowlanym. Wykorzystywanie przez pracodawców sytuacji dużego bezrobocia dla fizycznej i materialnej eksploatacji pracowników jest nie do pogodzenia ze społecznym nauczaniem Kościoła.

Naganną praktyką dla chrześcijańskiego przedsiębiorcy jest też uczestniczenie w zmowach cenowych $\mathrm{z}$ innymi przedsiębiorcami w celu zawyżania cen wytwarzanych dóbr powyżej ich wartości godziwej, odzwierciedlającej rzeczywisty wkład pracy niezbędny do ich wytworzenia. Zawyżanie cen godzi ostatecznie w konsumentów, a więc i w pracowników. Niegodziwe jest również wykorzystywanie sytuacji monopolistycznej w wytwarzaniu danego dobra w celu osiągnięcia dodatkowej korzyści. Inną budzącą sprzeciw praktyką jest dostarczanie dóbr i usług niewłaściwej jakości. Ten sposób osiągania dodatkowego zysku dokonuje się przecież również kosztem użytkowników nabywanych produktów.

Rozpowszechnionym zjawiskiem we współczesnych stosunkach ekonomicznych, nacechowanych walką konkurencyjną, jest zjawisko korupcji. Najczęściej przybiera ono formę wręczania łapówek w celu uzyskania zamówień produkcyjnych. Kryterium uzyskania zamówienia czy wygrania przetargu powinna być rzeczywista jakość składanej oferty. Motywem oferty korupcyjnej jest natomiast 
uzyskanie dochodu na drodze oszustwa. Oferta korupcyjna nie jest bowiem $\mathrm{w}$ stanie sprostać uczciwym kryteriom wymaganym przy realizacji planowanego przedsięwzięcia. Zjawisko korupcji jest szczególnie rozpowszechnione na styku sektora prywatnego i sektora publicznego, gdzie pewność uzyskania dodatkowego dochodu jest duża. Przekupywanie urzędników państwowych w celu zdobycia intratnych zamówień publicznych jest praktyką stosowaną zarówno w skali krajowej, jak i międzynarodowej. W tym drugim przypadku ociera się nawet o szkodę własnego kraju. Istotne jest jednak, że skutkiem przestępstw korupcyjnych $\mathrm{w}$ relacjach między sektorem publicznym i prywatnym są straty ekonomiczne, które ponosi całe społeczeństwo.

Przedsiębiorca przestrzegający zasad etyki chrześcijańskiej nie może uczestniczyć w takich praktykach, nawet gdyby miał utracić potencjalny dochód, który chciałby przeznaczyć na szlachetny cel. Korupcja równoznaczna jest bowiem z czyjąś krzywdą.

Postawą godną chrześcijanina jest gotowość darowania długów współbraciom, którzy doświadczyli trudności materialnych i nie są w stanie spłacić swych zobowiązań, zwłaszcza gdy trudności finansowe wynikają z przyczyn obiektywnych. Dotyczy to zarówno podległych przedsiębiorcy pracowników, jak i partnerów w biznesie. Umiejętność darowania długów to przecież element chrześcijańskiej nauki o przebaczaniu. Taka umiejętność jest darem.

Realizacja praktyki sprawiedliwości nie może ograniczać się tylko do stosunków w ramach samego przedsiębiorstwa. Funkcjonuje ono wszak w pewnej przestrzeni społeczno-kulturowej. Przedsiębiorca kierujący się etyką chrześcijańską ma za zadanie włączać się w rozwiązywanie problemów społeczności lokalnych, szczególnie w obszarach, w których państwo nie realizuje należycie swoich zadań. Papież Franciszek mówił, że „sprawiedliwy to ten, komu leży na sercu los mniej uprzywilejowanych i uboższych, kto nie ustaje w działaniu i jest gotów wytyczać wciąż nowe drogi. Tu właśnie chodzi o tę tak ważną kreatywność”2.

Słowa papieża Franciszka można rozumieć jako zachętę dla przedsiębiorców do aktywności biznesowej w celu tworzenia nowych miejsc pracy, do walki z plagą bezrobocia. Kreatywności biznesowej powinna jednak towarzyszyć nieustanna dobroczynność wobec tych, którzy cierpią niedostatek. Dzielenie się zyskiem z ubogimi, chorymi jest dopełnieniem aktywności zawodowej przedsiębiorcy. W kolejnej przypowieści Jezus mówi: „Bo byłem głodny, a daliście Mi jeść; byłem spragniony, a daliście Mi pić; byłem przybyszem, a przyjęliście Mnie; byłem nagi, a przyodzialiście Mnie; byłem chory, a odwiedziliście Mnie; byłem w więzieniu, a przyszliście do Mnie"(Mt 25, 35-36). Szczególnie cenna jest pomoc w sferze opieki medycznej. Zapaść służby zdrowia w Polsce najbardziej dotyka ludzi

2 http://m.niezalezna.pl/68206-papiez-spotkal-sie-z-przedsiebiorcami (2.10.2016). 
ubogich, już przez los pokrzywdzonych. Podobnie proces starzenia się polskiego społeczeństwa i potrzeba opieki nad ludźmi starymi generują olbrzymie koszty, którym państwo nie jest w stanie podołać. Bez materialnego wsparcia z funduszy prywatnych tych narastających problemów nie uda się rozwiązać.

Pomnażanie zysku bez pomocy bliźniemu nie ma sensu. Bogactwo jest po to, aby się nim dzielić z tymi, którzy cierpią niedostatek. Współczesny przedsiębiorca ma czynić tak jak ewangeliczny miłosierny Samarytanin, który bezinteresownie pomógł nieznajomemu napadniętemu przez zbójców. Takie postępowanie przyciąga do wiary chrześcijańskiej ludzi wątpiących, poszukujących. Pokazuje, że warto być chrześcijaninem.

Przedsiębiorca chrześcijański ma także obowiązek moralny, by włączać się w materialne dzieła charytatywne służące rozwojowi wspólnot chrześcijańskich. Bardzo ważnym tego wyrazem jest materialne wspieranie dzieł misyjnych Kościoła. Działalność misji katolickich wymaga znacznych środków materialnych. Ewangelizacji wśród tych, którzy nie słyszeli jeszcze Słowa Bożego, powinna towarzyszyć działalność charytatywna w sferze opieki medycznej i szkolnictwa. Pomoc materialna jest przecież wyrazem chrześcijańskiej miłości bliźniego, uwiarygodnieniem słów o Dobrej Nowinie.

Nie chodzi jednak o to, aby przeznaczać na powyższe cele środki z tego, co zbywa, lecz aby ograniczyć swoje wydatki materialne jako dar poświęcony Bogu. Przedsiębiorca uważający się za chrześcijanina powinien obalić smutną prawdę o ludziach wierzących, że Kościół żyje z pomocy ludzi biednych, a nie bogatych. Pomocy bliźniemu musi jednak towarzyszyć żarliwa modlitwa. Pomoc bliźniemu i modlitwa to bowiem dwa skrzydła prowadzące nas ku chrześcijańskiej doskonałości. Kościół uczy nas też jednak, że wiara bez dobrych uczynków jest martwa. Odnosi się to szczególnie do tych, którzy mają dużo. Dając nam za wzór miłosiernego Samarytanina, Jezus mówi: „Idź i ty czyń podobnie” (Łk 10, 37).

\section{Abstract}

\section{Present-day entrepreneur as a good Samaritan}

It is considered to be a well known fact that business and ethics can perfectly complement each other and constitute the core values of Christianity. As the most remarkable example may serve the biblical parable about the merciful Samaritan, who being on the way to Jerycho took care of a wounded man. His behavior reflects upon the gist of Christian morality, which deeply rooted in the biblical tradition, places emphasis on humility and extraordinary devotion.

An important aspect of Christian ethics issue in modern market economy relations between employers and employees. Business incomes may not be accumulated at the cost 
of employees ' harm. Wage payment deceiving or wage payment delays are immoral for Christian businesses. The concept of a fair wage so widely discussed by Pope John Paul II gives its focus to a harmonious cooperation between work and capital.

Another moteworthy issue of Cristian business concentrates on foregiveness of debts, especially to those in need.. Truly Christian entrepreneur focuses its aims on sharing benefits with the disadvantaged.

Profit cannot be the final purpose of human activity. Truly Christians focuses its aims at sharing business benefits with those who are disadvantaged

Wealth should be distributed fruitfully for humanitarian purposes. A Christian entrepreneur should be engaged in solving problems of local communities, above all in the areas where the state doesn 't fulfils its promises. A good exemplification can be health care, care for under-nourished or material assistance to unemployed. Another field of Christian activity can be material support of catholic missions which spread "Gods" word" across the globe.

Nevertheless, that sort of charity must be accompanied by keen prayer. Our Pope Francis always underlines the significance of prayer as the source of Christian excellence and the only possible way of improving social relations. Business ethics as an expression of charity and keen prayer are two wings which lead us to God. 